\title{
CONFINEMENT OF MICRONUCLEUS ON DAWKINSIA TAMBRAPARNIEI BY THE PARADOXICAL EFFECT OF THE ARSENIC DERIVATIVES
}

\author{
VIJAY VELU, RAMESH UTHANDAKALAIPANDIAN*
}

Department of Molecular Biology, School of Biological Sciences, Madurai Kamaraj University, Madurai, Tamil Nadu, India. Email: ramesh.biological@mkuniversity.org

Received: 10 April 2017, Revised and Accepted: 03 May 2017

\section{ABSTRACT}

Objective: In the current study, in vivo genotoxic effects of arsenic derivatives such as arsenic trioxide $\left(\mathrm{As}_{2} \mathrm{O}_{3}\right)$ and sodium arsenite $\left(\mathrm{NaAsO}_{2}\right)$ on peripheral blood erythrocytes of Dawkinsia tambraparniei were investigated using the micronucleus (MN) test.

Methods: MN staining was done using acridine orange pre-coated slides. Fluorescent microscope was used for scoring.

Results: In $\mathrm{NaAsO}_{2}$ exposed, the erythrocytes highest value was recorded at 42 days which is twofold higher than exposure at 7 days when compared to $\mathrm{As}_{2} \mathrm{O}_{3}$. Highest percentage was recorded about 13.9 in $\mathrm{NaAsO}_{2}$, and in case of $\mathrm{As}_{2} \mathrm{O}_{3}$, it was recorded as $0.2 \%$ less. It was clearly confirmed that either form of arsenic is toxic to organism.

Conclusion: Anthropogenic activities have also brought in substantial amounts of them into the environment by mobilization from their natural insoluble deposits or environmental sins. Hence, arsenic pollution should have measured, and arsenic removal process should have carried out.

Keywords: Micronucleus, Blood, Arsenic trioxide, Sodium arsenite, Toxicity.

(C) 2017 The Authors. Published by Innovare Academic Sciences Pvt Ltd. This is an open access article under the CC BY license (http://creativecommons. org/licenses/by/4. 0/) DOI: http://dx.doi.org/10.22159/ajpcr.2017.v10i8.19074

\section{INTRODUCTION}

Current awareness of the potential hazards of heavy metals in the aquatic environment has stimulated much interest in the use of fishes as indicators of biomonitoring of environmental carcinogens, teratogens, and mutagens. Arsenic one of the major natural as well as natural pollutants produces biochemical changes in the organs of accumulated animals due to its possible toxicity. Through gills and skin, the arsenic compounds pass through it and produce toxicity. In groundwater, arsenic content has a moderate level of 1-2 $\mu \mathrm{g} / \mathrm{L}$, but in certain cases, the level was increased up to $1000 \mu \mathrm{g} / \mathrm{Lin}$ several countries including India [1]. The arsenic content in Thamirabarani river drinking water system, groundwater is slightly higher $>0.01 \mathrm{mg} / \mathrm{L}$, it is far recommended to curtail the used arsenic-bearing insecticides for agricultural activities and usage of arsenic filters on the sites of pumping stations of Thamirabarani river consuming water machine and at effluents locations of automobile and commercial areas at the upstream location of the Thamirabarani river [2].

The DNA molecule is a target site of most, if not all, carcinogenic and mutagenic agents. The micronucleus (MN) test is considered to be one of the most useful methods for evaluating genotoxicity in aquatic systems. MN is formed by chromosome fragments or whole chromosomes that lag at cell division due to the lack of centromere, damage, or a defect in cytokinesis [3]. Erythrocytes are the most commonly used cells in the piscine MN test. In fish, erythrocyte MN and nuclear abnormalities (NAs) also emerge unconsciously, and their frequencies may be reliant to the season [4].

Dawkinsia tambraparniei (Silas, 1953) is an endangered cyprinid found only in streams of the Thamirabarani river system in the South Western Ghats, India. As with many other stream fishes of India, there may be little or no records on the distribution [5]. In fish, exposure to chemical pollutants can induce either will increase or decrease in hematological stages. Their changes depend on fish species, age, the cycle of the sexual maturity of spawners, and diseases [6]. Although arsenic toxicity greatly depends on its chemical forms, a few studies have taken into consideration the paradoxical phenomenon which is manifested by that sodium arsenite $\left(\mathrm{NaAsO}_{2}\right)$ acts as a mighty carcinogen; however, arsenic trioxide $\left(\mathrm{As}_{2} \mathrm{O}_{3}\right)$ serves as a powerful therapeutic agent. In the present study, in vivo genotoxic effects of $\mathrm{As}_{2} \mathrm{O}_{3}$ and $\mathrm{NaAsO}_{2}$ on peripheral blood erythrocytes of $D$. tambraparniei were investigated using the MN test.

\section{METHODS}

\section{Test species}

D. tambraparniei adults (length: $6 \pm 0.2$; weight: $4 \pm 0.3$ ) total of 100 fishes were caught by means of the fishing net at Papanasam (Thamirabarani river), Tamil Nadu, India. It was acclimatized in laboratory conditions in glass tanks for a minimal period of 14 days. It was maintained under temperature conditions of $25 \pm 2^{\circ} \mathrm{C}, 12 \mathrm{~h} / 12 \mathrm{~h}$ light/dark cycle. At the time of the experiment, the fish was fed with Artemia.

\section{Test chemicals}

$\mathrm{NaAsO}_{2}$ and acridine orange were purchased from Hi Media, Mumbai, and $\mathrm{As}_{2} \mathrm{O}_{3}$ was purchased from Sigma-Aldrich, UK.

\section{Lethality study}

The $\mathrm{LC}_{50}$ values for $\mathrm{As}_{2} \mathrm{O}_{3}$ and $\mathrm{NaAsO}_{2}$ were determined using the arithmetic method of Sprague [7] and were set up to be 570 and $585 \mu \mathrm{M}$, respectively. Fishes were maintained in a glass tank of $25 \mathrm{~L}$ capacity besides continuous air supply was given throughout the experiment. The physicochemical characteristics of test water were maintained accordingly by APHA standards, such as $\mathrm{pH}$ (7-7.2), total alkalinity (125-131 mEq/L), total hardness (200-205 mg/L as $\left.\mathrm{CaCO}_{3}\right)$, calcium (50-56 mg/L), magnesium $(18-22 \mathrm{mg} / \mathrm{L})$, and DO (89-90 mg/L). At experimental duration, the water was changed every day and the fecal materials were taken away. All over the experiment, physicochemical parameters were set.

\section{Experimental study}

The observational work was conducted to examine the effect of $\mathrm{As}_{2} \mathrm{O}_{3}$ and $\mathrm{NaAsO}_{2}$ by the method of Huntsman [8]. The fish was acclimatized 
and grouped as follows in triplicate containing 7 fishes in each group and it was divided into Group I-III such as Group I: Negative control group, Group II: $\mathrm{As}_{2} \mathrm{O}_{3}$ intoxicated group, and Group III: $\mathrm{NaAsO}_{2}$ intoxicated group. The fishes were exposed for 45 days (chronic).

\section{MN analysis}

After the experimental period was over, the blood of the exposed fishes was collected by a caudal puncture and coated with pre-cleaned slides. The slides were then fixed with ethanol for $20 \mathrm{~min}$ and air dried. The smears were stained with acridine orange in a concentration of $0.003 \%$ dissolved in phosphate buffer. The stained slides were viewed under a fluorescent microscope and evaluated for the presence of MN exhibiting under a bright field in the blood. Short, non-refractive, round, or oblong chromatin bodies, demonstrating the same staining and focusing arrangement as the main nucleus, were scored as MN. The stained erythrocytic cells were viewed under an epifluorescent microscope with a magnification capacity of $\times 100$ and appraise the presence of MN exhibiting bright orange colored. Erythrocytes were scored on each 1000 erythrocyte sample per fish. Obtained results were presented as a frequency (\%). It was calculated using the formula:

$$
\frac{1 \mathrm{xMN}+2 \mathrm{xBN}+3 \mathrm{xTN}+4 \mathrm{xTeN}}{1000}
$$

Where MN: Mononuleated, BN: Binucleated, TN: Trinucleated, TeN: Nucleated.

\section{Statistical analysis}

Means and standard errors were calculated for all data points from replicates. The means were compared between samples by Student's $\mathrm{t}$-test analysis using SPSS, and $\mathrm{p} \leq 0.05$ was considered statistically significant.

\section{RESULT AND DISCUSSION}

Each $\mathrm{NaAsO}_{2}$ and $\mathrm{As}_{2} \mathrm{O}_{3}$ is the two foremost modes of inorganic trivalent arsenic. Importantly, $\mathrm{NaAsO}_{2}$ is a properly documented carcinogen, even as $\mathrm{As}_{2} \mathrm{O}_{3}$ seems to be not only a poison, however, additionally an effective therapeutic tool in the treatment of acute promyelocytic leukemia and some stable tumors. To expose the difference among $\mathrm{NaAsO}_{2}$ and $\mathrm{As}_{2} \mathrm{O}_{3}$ in the induction of genotoxicity in peripheral blood erythrocytes, MN assay was performed. On exposure, it was found that $\mathrm{As}_{2} \mathrm{O}_{3}$ possesses a more $\mathrm{MN}$ frequency when compared to $\mathrm{NaAsO}_{2}$. These findings imply that $\mathrm{NaAsO}_{2}$ and $\mathrm{As}_{2} \mathrm{O}_{3}$ differently have an effect on chromosomal breakage and DNA injury, which may be interlinked with their unique capacity to trigger oxidative stress [9].

As by days, the $\mathrm{MN}$ frequency got increased in $\mathrm{As}_{2} \mathrm{O}_{3}$ when compared to $\mathrm{NaAsO}_{2}$. The changes in nucleus and MN formation are shown in Fig. 1. Thus, the exposure of arsenic-based MN frequency is purely on dose dependent, since a low dose of arsenic may also induce MN formation.

Susceptibility of arsenic in fish was determined to induce MN of their erythrocytes. Momentous increases in micronucleated cells have been determined in all the exposed fishes. The frequency of MN induction extended with corresponding growth in the exposure level, suggesting a dose-dependent increase in genotoxic indices. The MN assay needs a vast fraction of the cellular population treated with a genotoxic agent must undergo mitosis in order that the chromosomal anomalies prompted during the first mobile cycle are seen as MN within the cytoplasm at some points of the second or next cell cycles [10]. The frequency of cells nuclear bud and cells with MN improved considerably in fish exposed to the highest concentration. Lobed nuclei and blebbed nuclei were also observed in some cases [11].

The MN frequencies obtained among $\mathrm{NaAsO}_{2}$ and $\mathrm{As}_{2} \mathrm{O}_{3}$ inductions were tabulated in Tables 1 and 2, respectively. Just like MN frequencies of $\mathrm{NaAsO}_{2}$, the $\mathrm{MN}$ frequencies in fish exposed to $\mathrm{As}_{2} \mathrm{O}_{3}$ were notably higher $(\mathrm{p}<0.05)$. However, when compared $\mathrm{As}_{2} \mathrm{O}_{3}$ found to produce more $\mathrm{MN}$ frequency when compared to $\mathrm{NaAsO}_{2}$. Comparison of $\mathrm{MN}$ frequencies in fish exposed to $\mathrm{As}_{2} \mathrm{O}_{3}$ and $\mathrm{NaAsO}_{2}$ revealed a strong correlation between the expressions of $\mathrm{MN}$ and nuclear buds in peripheral erythrocytes. Interestingly, it was found that there is a slight decrease in MN frequency at 42 days of exposure. Since the fish was treated daily dealt with toxicant, there may be questionable remark that the fish will get adopted to the chemical for survival. However, the ratio of MN was not reduced drastically. The percentage of MN frequency in blood cells of $D$. tambraparniei after exposure to $\mathrm{NaAsO}_{2}$ and $\mathrm{As}_{2} \mathrm{O}_{3}$ of $7,14,28,35$, and 42 days, respectively, was graphically represented in Fig. 2. The formation of MN and other nuclear dissimilarities may be due to caspase-activated DNase, resulting in cleavage of cytoskeleton

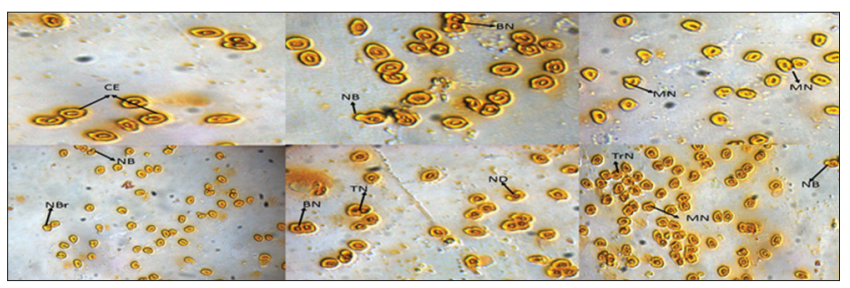

Fig. 1: Erythrocyte of fish stained with acridine orange and viewed under a fluorescent microscope. CE: Control erythrocytes, NB: Nuclear bud, NBr: Nuclear bridge, MN: Micronucleus, BN: Binucleated, TN: Trinucleated, TrN: Tetranucleated

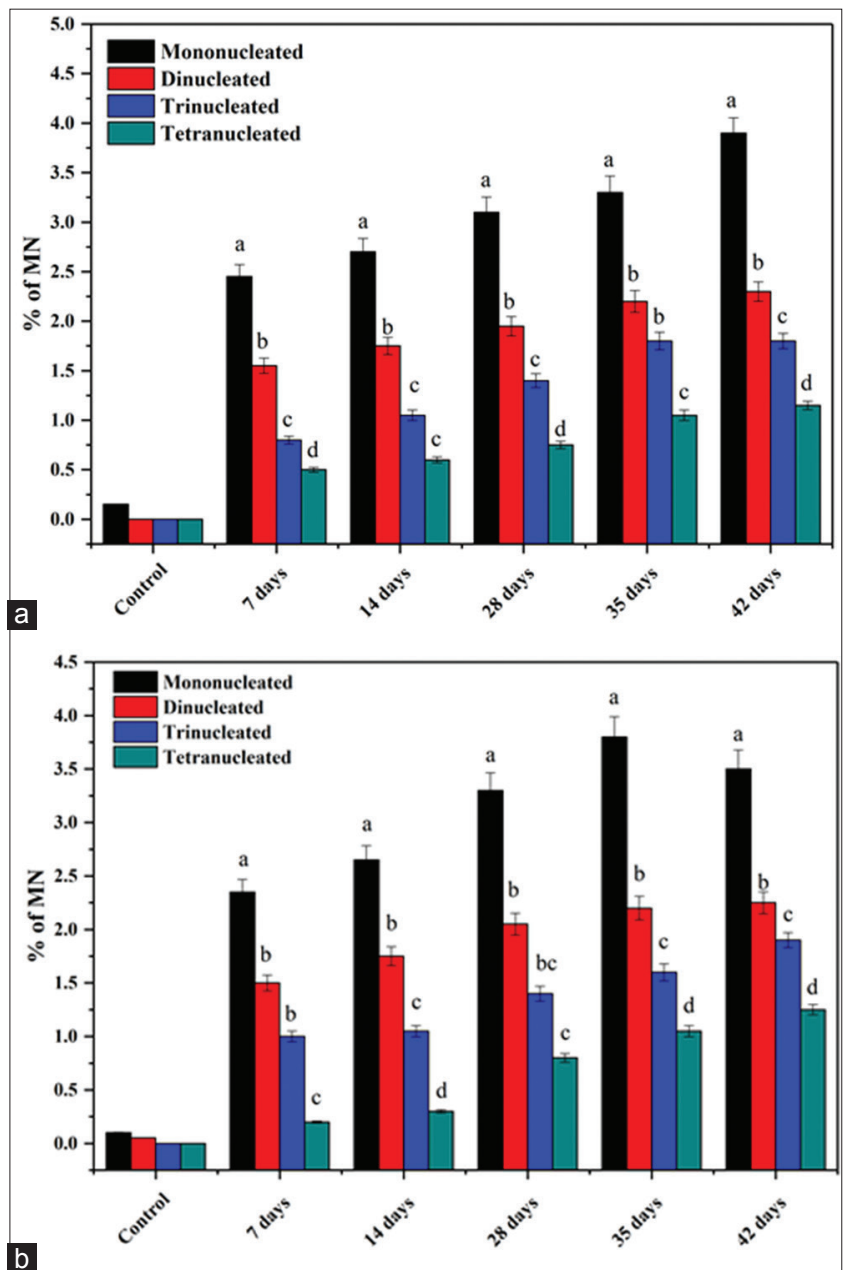

Fig. 2: \% Micronucleus values in blood cells of Dawkinsia tambraparniei after exposure to (a) arsenic trioxide and (b) sodium arsenite. a, b, c, and d: Significant differences from the control at $p<0.05$ on exposure of $7,14,28,35$, and 42 days shown in column, respectively 
Table 1: MN frequencies in erythrocyte of $D$. tambraparniei exposed to sodium arsenite

\begin{tabular}{|c|c|c|c|c|c|c|c|c|}
\hline \multirow[t]{2}{*}{ Duration of exposure (days) } & \multirow[t]{2}{*}{ Number of cells scored } & \multicolumn{4}{|c|}{ Number of cells with MN } & \multirow[t]{2}{*}{ Total } & \multirow[t]{2}{*}{ MN frequency (\%) } & \multirow[t]{2}{*}{ Mean (\%) $\pm S E$} \\
\hline & & 1 & 2 & 3 & 4 & & & \\
\hline Control & 1000 & 1 & 0 & 0 & 0 & 1 & 0.2 & $0.03 \pm 0.047$ \\
\hline 7 & 1000 & 17 & 13 & 7 & 2 & 39 & 8.35 & $1.26 \pm 0.9$ \\
\hline 14 & 1000 & 21 & 16 & 9 & 5 & 51 & 9.3 & $1.43 \pm 1.002$ \\
\hline 28 & 1000 & 26 & 16 & 9 & 8 & 59 & 11.6 & $1.88 \pm 1.07$ \\
\hline 35 & 1000 & 32 & 22 & 12 & 9 & 75 & 13.004 & $2.16 \pm 1.18$ \\
\hline 42 & 1000 & 39 & 23 & 18 & 12 & 92 & 13.9 & $2.28 \pm 1.17$ \\
\hline
\end{tabular}

D. tambraparniei: Dawkinsia tambraparniei, MN: Micronucleus, SE: Standard error

Table 2: MN frequencies in erythrocyte of D. tambraparniei exposed to arsenic trioxide

\begin{tabular}{|c|c|c|c|c|c|c|c|c|}
\hline \multirow[t]{2}{*}{ Duration of exposure (days) } & \multirow[t]{2}{*}{ Number of cells scored } & \multicolumn{4}{|c|}{$\begin{array}{l}\text { Number of cells with } \\
\text { MN }\end{array}$} & \multirow[t]{2}{*}{ Total } & \multirow[t]{2}{*}{ MN frequency (\%) } & \multirow[t]{2}{*}{ Mean $(\%) \pm S E$} \\
\hline & & 1 & 2 & 3 & 4 & & & \\
\hline 7 & 1000 & 24 & 15 & 8 & 5 & 52 & 7.95 & $1.32 \pm 0.87$ \\
\hline 14 & 1000 & 27 & 17 & 10 & 6 & 60 & 9.35 & $1.52 \pm 0.91$ \\
\hline 28 & 1000 & 31 & 19 & 14 & 7 & 71 & 11.2 & $1.8 \pm 0.99$ \\
\hline 35 & 1000 & 33 & 22 & 18 & 10 & 83 & 13.1 & $2.08 \pm 0.93$ \\
\hline 42 & 1000 & 35 & 22 & 19 & 13 & 89 & 13.7 & $2.22 \pm 0.94$ \\
\hline
\end{tabular}

D. tambraparniei: Dawkinsia tambraparniei, MN: Micronucleus, SE: Standard error

(fodrin, vimentin, and gelsolin) and nuclear proteins, leading to mitochondrial damage [12].

In $\mathrm{NaAsO}_{2}$ exposed, the erythrocytes highest value was recorded at 35 days. A number of MN counted for 1000 cells are about 32 which is twofold higher than exposure at 7 days. This indicates whenever there is a flow of continuous anthropogenic activities will be a chance of exhibition of more MN in affected aquatic species. A lower proportion of young erythrocytes in peripheral blood of D. tambraparniei was found to be $8.3 \%$, and a higher proportion was found to be $13 \%$. Likewise, $\mathrm{NaAsO}_{2}$ in $\mathrm{As}_{2} \mathrm{O}_{3}$ exposed, the erythrocytes highest value was recorded at 35 days, and slight changes occurred in MN frequency at 42 days.

The outcomes of Ahmed [13] confirmed the importance of fish liver as capacity biomarker of arsenic toxicity for comet assay. The suitability of peripheral blood MN assay suggests its broader application as an early organic marker of exposure of fish to pollutants in the aquatic environment.

The genotoxic capability of acute concentrations of $\mathrm{NaAsO}_{2}$ determined on this research advised severe difficulty toward its potential dangers to aquatic organisms. The average frequency of MN in fishes exposed to As (III) 12.03 was reported by Yadav [14] in Channa punctatus, but in this case the average frequency of 13.10 which is when compared the reported fish. Strunjak-Perovic [15] suggested that evaluation of erythrocytes in triploid rainbow trout did no longer reveal the presence of any morphological NAs in spite of substantially better MN frequency in relation to ordinary, diploid fish suggesting that correlation between NAs and MN is an end result of clastogenic but not aneugenic effects. Arsenic also causes damage to the liver as well as gills, in such cases, erythrocytes also got damaged [16,17]. Insufficient studies have taken into consideration to distinguish the precise molecular foundation of $\mathrm{NaAsO}_{2}$ carcinogenicity and the anticancer effect of $\mathrm{As}_{2} \mathrm{O}_{3}$ in an experiment. In such case, the present study shows the affiliation between $\mathrm{As}_{2} \mathrm{O}_{3}$ and $\mathrm{NaAsO}_{2}$.

\section{CONCLUSION}

The present study conducted shows acridine orange staining that shows differentiation of NAs. In addition, with this paradoxical effect of arsenic compounds such as $\mathrm{NaAsO}_{2}$ and $\mathrm{As}_{2} \mathrm{O}_{3}$ were seen. Arsenic in any form dissolves in water easily. Both chemicals have genotoxic effects in fish. The results of this study demonstrated that the river as well as stream fish species need to be conserved, hence, it is in endangered condition because the arsenic compounds cannot be destroyed easily in the environment, and thus D. tambraparniei test could be a sensitive and useful tool for evaluation of genotoxic effects in Thamirabarani river ecosystem.

\section{ACKNOWLEDGMENT}

The author would like to thank DST-INSPIRE Fellowship Scheme for the funding and Madurai Kamaraj University UGC-NRCBS for providing instrumentation facility.

\section{REFERENCES}

1. Chakraborti D, Das B, Rahman MM, Chowdhury UK, Biswas B, Goswami AB, et al. Status of groundwater arsenic contamination in the state of West Bengal, India: A 20-year study report. Mol Nutr Food Res 2009;53(5):542-51.

2. Manimaran D, Manimaran G. Arsenic contamination of groundwater in Vallanadu region of Tuticorin district, Tamilnadu, India. Online Int Interdiscip Res J 2013;3:230-42.

3. Heddle JA, Cimino MC, Hayashi M, Romagna F, Shelby MD, Tucker JD, et al. Micronuclei as an index of cytogenetic damage: Past, present, and future. Environ Mol Mutagen 1991;18(4):277-91.

4. Bolognesi C, Perrone E, Roggieri P, Pampanin DM, Sciutto A. Assessment of micronuclei induction in peripheral erythrocytes of fish exposed to xenobiotics under controlled conditions. Aquat Toxicol 2006;78 Suppl 1:S93-8.

5. Arunachalam M, Murugan M. Cytogenetics and cytotaxonomic consideration of two endangered ornamental fishes Puntius arulius and P. Tambraparniei (Cypriniformes: Cyprinidae) from Western Ghats, India. Zoo's Print J 2007;22(7):2739-41.

6. Luskova V. Annual cycles and normal values of hematological parameters in fishes. Acta Sci Nat Acad Sci Bohemicae Brno 1997;31(5):70-8.

7. Sprague JB. Measurement of pollutant toxicity to fish I. Bioassay methods for acute toxicity. Water Res 1969;3(11):793-821.

8. Huntsman AG, Sparks MI. No. 6: Limiting factors for marine animals: 3. Relative resistance to high temperatures. Contrib Can Biol Fish 1924;2(1):95-114

9. Hei TK, Filipic M. Role of oxidative damage in the genotoxicity of arsenic. Free Radic Biol Med 2004;37(5):574-81.

10. Tates AD, Neuteboom I, Hofker M, den Engelse L. A micronucleus technique for detecting clastogenic effects of mutagens/carcinogens (DEN, DMN) in hepatocytes of rat liver in vivo. Mutat Res Environ Mutagen 1980;74(1):11-20. 
11. Ghaffar A, Hussain R, Aslam M, Abbas G, Khan A. Arsenic and urea in combination alters the hematology, biochemistry and protoplasm in exposed Rohu fish (Labeo rohita) (Hamilton, 1822). Turk J Fish Aquat Sci 2016;16(2):289-96.

12. Hussain R, Khan A, Mahmood F, Rehan S, Ali F. Clinico-hematological and tissue changes induced by butachlor in male Japanese quail (Coturnix japonica). Pestic Biochem Physiol 2014;109:58-63.

13. Ahmed MK, Habibullah-Al-Mamun M, Hossain MA, Arif M, Parvin E, Akter MS, et al. Assessing the genotoxic potentials of arsenic in tilapia (Oreochromis mossambicus) using alkaline comet assay and micronucleus test. Chemosphere 2011;84(1):143-9.

14. Yadav KK, Trivedi SP. Sublethal exposure of heavy metals induces micronuclei in fish, Channa punctata. Chemosphere 2009;77(11):1495-500

15. Strunjak-Perović I, Č́ož-Rakovac R, Popović NT. Micronucleus occurrence in diploid and triploid rainbow trout (Oncorhynchus mykiss Walbaum). Vet Med 2003;48(8):215-9.

16. Al-Harbi MS. Hepatoprotective effect and antioxidant capacity of naringenin on arsenic-induced liver injury in rats. Int $\mathrm{J}$ Pharm Pharm Sci 2016;8(4):103-8.

17. Vijay V, Ramesh U. Efficacy of microdoses potentized homeopathic drug, arsenicum album induced by arsenic trioxide in zebrafish (Danio rerio)-a FTIR study in gills. Int J Pharm Pharm Sci 2017;9(1):48-51. 